\title{
Influence of intrinsic factors on conventional wine protein stability tests
}

\author{
M.R. Sarmento ${ }^{\text {a }}$, J.C. Oliveira ${ }^{\text {b,*}}{ }$, M. Slatner ${ }^{c}$, R.B. Boulton ${ }^{d}$ \\ ${ }^{a}$ Escola Superior de Biotecnologia, U.C.P., R. Dr. António B. Almeida, Porto, Portugal \\ ${ }^{\mathrm{b}}$ Department of Food Science and Technology, University College Cork, Cork, Ireland \\ ${ }^{\mathrm{c}}$ Universitat fur Bodenkultur, Vienna, Austria \\ ${ }^{\mathrm{d}}$ Department of Viticulture and Enology, University of California, Davis, CA 95616, USA
}

Keywords: Protein precipitation; Wine protein profile; Wine storage

\begin{abstract}
The influence of intrinsic factors on the results of ethanol, tannin and heat tests, routinely used to assess wine protein stability, was studied. Experiments were performed on 23 Portuguese and Austrian wines. The factors considered were total protein content, $\mathrm{pH}$, ethanol content and the amount of several relevant cations (calcium, iron, copper, sodium and potassium). The protein profiles were analysed by HPLC fractionation. The heat test was a good indicator of total protein content while the ethanol and the tannin tests showed significant interference by the other factors. A factorial design at two levels in selected samples was also performed to assess the influence of $\mathrm{pH}$, storage temperature, tannin concentration and ethanol concentration on the development of turbidity. Results indicated that ethanol content had no significant influence, and that $\mathrm{pH}$ and storage temperature had a significant influence, though only when tannin was added. (C) 2000 Elsevier Science Ltd. All rights reserved.
\end{abstract}

\section{Introduction}

Wine proteins may become insoluble and precipitate causing the appearance of a haze, which looks unattractive in white and rosé wines, and may also be responsible for changes in taste (Troost, 1988). Precipitation may be due to intrinsically or extrinsically induced changes, such as in $\mathrm{pH}$, ethanol content, storage temperature and the amount of phenolic compounds (Boulton, 1980). These changes may arise during storage or when different wines are blended, which is an important processing operation in some wines.

Wine contains many different proteins, that are generally grouped in protein fractions because not all have been uniquely identified analytically (Hsu, Heatherbell, Flores \& Watson, 1987). A comprehensive understanding of how different wine protein profiles relate to instability problems is unfortunately not yet available. Several authors attempted to correlate the molecular

\footnotetext{
${ }^{*}$ Corresponding author. Tel.: +353-21-902748; fax: +353-21276398.

E-mail address: j.oliveira@ucc.ie (J.C. Oliveira).
}

weight and ionic properties of wine protein fractions with instability: Bayly and Berg (1967), using anion exchange chromatography on DEAE cellulose, found that the fractions with lower isoelectric point $(\mathrm{pI})$ were more sensitive to heat treatment; Hsu et al. (1987) and Mesrob, Gorinova and Tsakov (1983), both using electrophoresis, suggested that protein instability in wines is mainly caused by fractions with lower molecular weight and pI. Lamikanra and Inyang (1988) suggested that proteins with molecular weights higher than $32 \mathrm{kDalton}$ in muscadine wines are unstable. Waters, Wallace and Williams (1991), using a back-addition method, concluded that each protein fraction, obtained by ammonium acetate precipitation, exhibited different slopes on a plot of induced haze (A540 nm) vs. protein concentration $(\mu \mathrm{g} / \mathrm{ml})$, as measured by amino-acid quantification, and that the fractions dominated by either the molecular weights of $32 \mathrm{kDalton}$ or $24 \mathrm{kDalton}$ were the most susceptible to heat-induced haze. The same authors stated later (Waters, Wallace \& Williams, 1992) that the lower molecular weight proteins may be more important to wine haze, and found that the protein with $24 \mathrm{kDa}$ ton caused approximately $50 \%$ more haze, at the same concentration, than the protein with $32 \mathrm{kDalton}$. 
Later, Waters, Wallace and Williams (1996) found that wine soluble proteins had sequence homology to plant chitinases. Dawes, Boyes, Keene and Heatherbell (1994), using a modified Coomassie blue assay for protein quantification and an FPLC method to separate the protein groups, concluded that the differences in the degree of the stability of groups with different pI's, assessed by a heat test, are not significant when the variation in the original protein concentration in the samples is considered, although, when added back to the ultrafiltered wine, a marked difference of the precipitation/coagulation of different protein groups was observed. The visual observations were, however, not reflected in the spectrophotometric readings after homogenising the supernatant with the sediment.

Stability tests are needed in everyday industrial practice to assess if a wine may become protein-unstable and to determine the necessary amounts of bentonite to be added to each specific wine to prevent instability (bentonite removes the proteins by ion-exchange adsorption). A conventional stability test is based on causing the precipitation of proteins by some manner, assuming that the turbidity thus developed is the potential one over the period of storage.

Protein stability tests can be classified as total protein assays (Biuret, Coomassie blue), chemical denaturation (trichloroacetic acid, phosphomolybdic acid), heat denaturation, and decrease of the solubility, which can be achieved by increasing the ethanol content (Boulton, 1980) or the tannin content (Mesrob et al., 1983). Another alternative is the trichloroacetic acid (TCA) test, which involves boiling the sample for $5 \mathrm{~min}$ with TCA added, cooling and measuring haze formation. This test is based on the chemical destruction of the protein structures at $\mathrm{pH}$ below 1, and is therefore a crude measure of total protein (Boulton, 1980) and it was found to correlate well with the heat test (Bayly \& Berg, 1967).

Heat tests are most common in the industry. The sample is heated at a given temperature for a specific period of time and the heat denaturation thus induced causes precipitation. It has not been established whether some protein fractions are more sensitive than others and if they are, whether the result is the same as with low-temperature long-time precipitation, which is what happens during storage. A concern with heat tests is the accelerated oxidation and condensation of phenolic compounds with proteins, at high temperatures, which cause precipitation and can therefore interfere with the test results.

The ethanol precipitation test is based on the decrease in the dielectric constant, which will decrease the protein solubility (Lehninger, 1981). Therefore, it may be expected that this test will cause the precipitation of the least soluble fractions, at the wine $\mathrm{pH}$.

The tannin precipitation test is based on the assumption that proteins precipitate in wine during storage by linking to high molecular weight phenolic compounds, such as tannins. Previous work (Yokotsuka, Yoshii, Aihara \& Kushida, 1983) indicated that the ability of phenolic compounds to bind to proteins increases with the increase of their degree of polymerisation. Haggerman and Buttler (1981) stated that polymeric phenols might precipitate one protein when another protein is present in large excess. Therefore, the tannin test would provide information on the ability of the proteins of a certain wine to be precipitated by polyphenolic compounds.

The objectives of this work were: (1) to evaluate the more conventional stability tests, determining whether the results are affected by relevant intrinsic factors; (2) to identify if there are particularly sensitive fractions in the tests and in naturally occurring precipitation during wine storage; (3) to quantify the relative impact of changing $\mathrm{pH}$, temperature and ethanol and tannin contents on the development of protein hazes.

\section{Materials and methods}

\subsection{Wine samples}

Samples of white wines from different cultivars and growing regions and from two harvest years were generously supplied by several wineries prior to any protein removal process. This collection of industrially produced wines was complemented by some laboratory produced wines, made from grapes generously supplied by several vineyards. The samples are detailed in Table 1 . The most relevant wine cations (calcium, iron, sodium, potassium and copper) were quantified (by atomic absorption spectrophotometry) and the $\mathrm{pH}$ was determined using a $\mathrm{pH}$ meter. Results are shown in Table 1.

The laboratory microvinifications procedure was the following: grapes harvested in each vineyard were stored at $20^{\circ} \mathrm{C}$ for up to one week, transported (without temperature conditioning) to the laboratory and stored again for up to one week at approximately $20^{\circ} \mathrm{C}$. Grapes were manually separated from the stalks and crushed. A mild pressing was then performed using a small basket press. Selected yeasts (Saccharomyces cereviseae, n. 7013 INRA Narbonne, Gist Brocades, France) were previously activated and then added to the juice in the amount of $0.2 \mathrm{~g} / \mathrm{l}$, as indicated by the supplier. Fermentation was carried out in 51 bottles (demijohns) at room temperature (controlled at $20 \pm 1{ }^{\circ} \mathrm{C}$ ). Air traps were used to prevent the entrance of air and simultaneously allow the exit of carbon dioxide. The fermentation was monitored using aerometers. After fermentation, wines were allowed to settle at room temperature and decanted after approximately one week. Sodium metabisulphate was added, in the total amount of $200 \mathrm{mg} / \mathrm{l}$ wine. Wine samples were then 
Table 1

Origin, cultivars, total protein, $\mathrm{pH}$ and cation content of the wines studied (average of two replicates)

\begin{tabular}{|c|c|c|c|c|c|c|c|c|c|c|}
\hline \multirow{2}{*}{$\begin{array}{l}\text { Samples } \\
\text { reference }\end{array}$} & \multirow[t]{2}{*}{ Region } & \multirow[t]{2}{*}{ Cultivar } & \multirow[t]{2}{*}{ Production } & \multirow{2}{*}{$\begin{array}{l}\text { Protein } \\
\text { content } \\
(\mathrm{mg} / \mathrm{l})\end{array}$} & \multirow[t]{2}{*}{$\mathrm{pH}$} & \multicolumn{5}{|c|}{ Ion content $(\mathrm{mg} / \mathrm{l})$} \\
\hline & & & & & & $\mathrm{Ca}$ & $\mathrm{Fe}$ & $\mathrm{Na}$ & $\mathrm{K}$ & $\mathrm{Cu}$ \\
\hline WVGr & Wachau & Gr.Veltliner & Winery & 64.7 & 3.25 & n.d. ${ }^{b}$ & n.d. & n.d. & n.d. & n.d. \\
\hline WVGs & & Gr.Sylvaner & Winery & 49.4 & 3.41 & n.d. & n.d. & n.d. & n.d. & n.d. \\
\hline WVMx & & mixture & Winery & 22.6 & 3.52 & n.d. & n.d. & n.d. & n.d. & n.d. \\
\hline AUMc & Algarve & Moscatel & Lab. & 95.0 & 3.64 & 81.7 & 10.87 & 25.0 & 1177 & 0.027 \\
\hline AtUMt & Alentejo & Manteudo & Lab. & 1.45 & 2.95 & 40.7 & 5.05 & 68.7 & 975 & 0.027 \\
\hline AtUPr & & Perrum & Lab. & 21.9 & 3.45 & 43.5 & 9.70 & 67.1 & 995 & 0.053 \\
\hline BVRo & Bairrada & Rabo ovelha & Winery & 8.78 & 3.13 & 54.0 & 0.74 & 12.5 & 755 & 0.025 \\
\hline BVMg & & $\mathrm{M}^{\mathrm{a}}$ Gomas & Winery & 12.3 & 3.13 & 58.7 & 0.98 & 13.6 & 704 & 0.025 \\
\hline BVAr & & Arinto & Winery & 29.2 & 2.99 & 82.3 & 1.12 & 12.5 & 615 & 0.077 \\
\hline $\mathrm{BVCc}$ & & Cercial & Winery & 146.8 & 2.93 & 91.4 & 0.60 & 15.7 & 507 & 0.048 \\
\hline CUMv & Colares & Malvasia & Lab. & 11.9 & 3.06 & 74.3 & 11.24 & 62.7 & 591 & 0.321 \\
\hline CUMx(a) & & mix. (sand) & Lab. & 20.5 & 3.10 & 53.3 & 9.88 & 70.8 & 707 & 0.019 \\
\hline CUMx(r) & & mix. (earth) & Lab. & 119.9 & 3.29 & 63.1 & 0.43 & 7.9 & 878 & 0.130 \\
\hline DURb & Douro & Rabigato & Lab. & 23.4 & 3.52 & 37.0 & 4.35 & 74.4 & 694 & 0.018 \\
\hline DUCd & & Codega & Lab. & 28.2 & 3.64 & 39.2 & 2.79 & 54.2 & 853 & 0.020 \\
\hline VUFp & Valpaços & F. Pires & Lab. & 82.2 & 3.27 & 48.2 & 6.62 & 58.4 & 634 & 0.063 \\
\hline VUMv & & Malvasia & Lab. & 15.1 & 3.21 & 48.7 & 4.38 & 41.2 & 619 & 0.015 \\
\hline VUCd & & Codega & Lab. & 53.7 & 2.97 & 37.4 & 6.73 & 39.7 & 586 & 0.043 \\
\hline VVCd & & Codega & Winery & 9.21 & 3.06 & 53.8 & 1.52 & 12.6 & 569 & 0.043 \\
\hline VUGv & & Gouveio & Lab. & 51.3 & 3.09 & 58.9 & 5.67 & 23.3 & 585 & 0.045 \\
\hline VVGV & & Gouveio & Winery & 206.8 & 3.20 & 56.4 & 4.04 & 19.8 & 567 & 0.215 \\
\hline MULr & Minho & Loureiro & Lab. & 26.0 & 3.07 & 47.0 & 8.09 & 64.7 & 859 & 0.015 \\
\hline MUAz & & Azal & Lab. & 10.2 & 2.92 & 37.4 & 6.75 & 34.2 & 1094 & 0.007 \\
\hline
\end{tabular}

${ }^{\text {a }}$ The reference is built as follows: the first capital and lower case letter, when present, indicate the growing region; the second capital indicates the production process ( $\mathrm{U}$ for laboratory, $\mathrm{V}$ for winery production); and the third capital and final lower case letter indicate the cultivar.

${ }^{\mathrm{b}}$ n.d. - not determined.

centrifuged at $5000 \mathrm{rpm}(3.25 \mathrm{~g})$ for $10 \mathrm{~min}$ and microorganisms were eliminated by filtration through $0.45 \mu \mathrm{m}$ membranes (Nucleopore, USA).

The turbidity caused by precipitation was measured in all cases by spectrophotometry at $560 \mathrm{~nm}$ (Unicam 8620, Phillips, Eindhoven, Holland).

\subsection{HPLC protein quantification}

Wine protein fractions were separated using the anion exchange HPLC method developed by Trousdale and Boulton (1987). A sample pre-treatment was necessary, consisting of a preliminary ultrafiltration to eliminate interfering substances and to concentrate the protein in the samples, in order to increase the detection signal. Discardable devices (Microsep concentrators, Filtron Tech., MA, USA), with $4 \mathrm{ml}$ of sample each, were placed in a centrifuge, that provided the driving force for ultrafiltration. A two-step ultrafiltration was required: (1) ultrafiltration through $300 \mathrm{KD}$ membranes, in order to eliminate higher molecular weight colloidal matter; (2) ultrafiltration of the filtrate of the first step through $10 \mathrm{KD}$ membranes. A temperature-controlled centrifuge (Sorvall, Dupont, USA) was used, at $6000 \mathrm{rpm}(3.89 \mathrm{~g}$ ) and $18^{\circ} \mathrm{C}$ for at least $3 \mathrm{~h}$, depending on the wine.

Preliminary work also indicated that the retentate thus obtained needed a three-stage diafiltration to re- move additional interferents, possibly phenolic compounds. The retentate was resuspended in de-ionised water prior to the diafiltration. A peak in the region of 310-330 nm decreased after each washing, and three washes were sufficient to remove it.

A Beckman HPLC system, with Beckman Module 126 pump and Beckman Module 166 UV detector, was used (Beckman, USA). According to the HPLC method (Trousdale \& Boulton, 1987), an injection volume of 10 $\mu 1$ with a constant flow rate of $1.0 \mathrm{ml} / \mathrm{min}$ was used and detection was performed at $280 \mathrm{~nm}$. The column was an ion-exchange Biorad Biogel SEC DEAE-5PW (Biorad Laboratories, Richmond, USA) with $5 \mu \mathrm{m}$ particle size and dimensions $75 \times 7.5 \mathrm{~mm}^{2}$. This column was used with a TRIS buffer at pH 8.0 (solution A). Elution was obtained with a gradient of $0.5 \mathrm{M} \mathrm{NaCl}$ in TRIS buffer at $\mathrm{pH} 8.0$ (solution B). Mobile phases were filtered through $0.22 \mu \mathrm{m}$ membrane filters and then degassed under vacuum for $1 \mathrm{~h}$ prior to use. A step-wise salt concentration profile was run by varying the ratios of solutions $\mathrm{A}$ and $\mathrm{B}$.

\subsection{Heat test}

Two versions of the heat test were applied to all wines, previously filtered through a $0.22 \mu \mathrm{m}$ membrane filter, in hermetically sealed $5.0 \mathrm{ml}$ chromatography vials 
(Chrompack, France). In the fast version, the duplicate wine samples were subjected to $90^{\circ} \mathrm{C}$ for $1 \mathrm{~h}$ in a thermostatic water bath, followed by $4^{\circ} \mathrm{C}$ for $6 \mathrm{~h}$, in a large cold room. After this treatment, the samples were equilibrated to room temperature $\left(20^{\circ} \mathrm{C}\right)$. In the mild version, the wine samples were submitted to $60^{\circ} \mathrm{C}$ for 4 days, then kept at $4^{\circ} \mathrm{C}$ for $6 \mathrm{~h}$ and finally equilibrated to room temperature. Developed turbidity was then measured against a blank of each untreated filtered wine sample. Samples were well-stirred before readings to prevent sedimentation. For every measurement, the average of three replicated samples was used.

\subsection{Ethanol test}

Five $\mathrm{ml}$ of pure ethanol was added to an equal volume of each degassed wine sample and held in closed flasks at room temperature for $2 \mathrm{~h}$. Induced turbidity was then measured at room temperature. For every measurement, the average of three replicated samples was used.

\subsection{Tannin test}

The method described by Mesrob et al. (1983), was used: $5.0 \mathrm{ml}$ of each wine sample was mixed with $0.4 \mathrm{ml}$ of a $1 \%$ tannin solution in $40 \%(\mathrm{v} / \mathrm{v})$ ethanol and held for $15 \mathrm{~min}$ at room temperature and then for $3 \mathrm{~min}$ in a boiling water bath. Induced turbidity was then read against a blank of untreated wine. The tannin solution was prepared by dissolving $1.0 \mathrm{~g}$ of enological wood tannin (Proenol, V.N. Gaia, Portugal) in $10.0 \mathrm{ml}$ of distilled water at $70^{\circ} \mathrm{C}$. When the tannin was well dissolved, $50.0 \mathrm{ml}$ of distilled water was then added and finally ethanol was added to make up a total volume of $100.0 \mathrm{ml}$. For every measurement, the average of three replicated samples was used.

\subsection{Natural precipitation}

All wines were stored for over one-year in closed chromatography vials (Chrompack, France) at room temperature (varying between $13^{\circ} \mathrm{C}$ and $23^{\circ} \mathrm{C}$ during the year). In the wines that showed a visible haze the turbidities of two duplicate samples were measured against a blank of $0.22 \mu \mathrm{m}$ membrane-filtered wine.

\subsection{Influence of different factors on the results of the stability tests}

The influence of the intrinsic factors on the test response (turbidity measured) was evaluated by means of multiple regression analysis for a multilinear model. Thus, the response is described by turbidity $=\sum_{i=1}^{7} \alpha_{i} f_{i}+\varepsilon$

where $\varepsilon$ is the error, $\alpha_{i}$ the several coefficients and $f$ is the normalised value of each factor. Values were normalised to improve regression precision, due to the different magnitudes involved. The value for normalisation was the highest of that factor in all samples. The factors considered were total protein content, $\mathrm{pH}$ and the content of each of the cations (calcium, iron, sodium, potassium and copper) of the original wine sample. The inclusion of the factors in the model was determined by stepwise regression (Hair, Anderson, Tatham \& Black, 1995 ) at the $95 \%$ confidence level using the Statview software (Statview, Abacus Concepts, 1992, Berkeley, USA). This regression involved a $t$-test, eliminating in each step a coefficient $\left(\alpha_{i}\right)$ that was not statistically different from zero, until all remaining coefficients were significant.

\subsection{Influence of changes in intrinsic factors on protein stability}

The ethanol content, $\mathrm{pH}$ and tannin content of different wine samples were adjusted at two levels, to perform a factorial design analysis. Representative wines were chosen from those listed in Table 1 . The resulting samples were stored for over one month and the turbidity developed was measured. The two levels were produced by applying the same type of variation to each sample, as indicated in Table 2, resulting in different values depending on the original parameters of the respective wine samples. It was considered that this leads to possible limits similar to the natural variation that can occur as a result of storage or blending. Two storage temperatures were used: a lower value $\left(20^{\circ} \mathrm{C}\right)$ which is usually the maximum storage temperature, and a higher value $\left(40^{\circ} \mathrm{C}\right)$ for providing a more extensive precipitation.

For each wine, an original $72 \mathrm{ml}$ sample was divided into two $36 \mathrm{ml}$ aliquots and $\mathrm{NaOH}$ or $\mathrm{HCl}$ was added to end up with $+15 \%$ of the original $\mathrm{pH}$ in one case and $-15 \%$ in the other. Each aliquot was then divided into two equal halves, adding enological wood tannin to one of them, to make up to a concentration of $1000 \mathrm{mg}$ of added tannin/l. Each of the four aliquots was subsequently divided into two equal halves, adding to one of them the required amount of ethanol to make up 15\% extra ethanol concentration. Each of the resulting eight aliquots was then divided into two, one being stored at the high temperature level and the other at the low level. Each aliquot stored was kept in closed $8 \mathrm{ml}$ chromatography vials (Chrompack, France) with the head space filled with nitrogen, for a minimum of 30 days. The design was replicated once. The order of analysis of the several samples including replicates was randomised. 
Table 2

Levels of the factors in the factorial design

\begin{tabular}{llll}
\hline Levels & $\mathrm{pH}$ & Ethanol & Tannin \\
\hline High $(-)$ & $-15 \%$ Original & Original \\
Low $(+)$ & $+15 \%$ Original & $+15 \%$ Original & Original \\
$1000 \mathrm{mg} / 1$ & 40 \\
\hline
\end{tabular}

\section{Results and discussion}

\subsection{The ethanol test}

The results of the stepwise model estimation indicate that total protein, calcium and the $\mathrm{pH}$ significantly influence the development of haze induced by the ethanol test. The magnitude of the several linear effects is shown by a Pareto chart in Fig. 1(a). With 95\% confidence, the $\mathrm{pH}$, the content of calcium ions and the total content of protein are sufficient to describe the response of a wine to an ethanol test. The model fit and distribution of residuals are shown in Fig. 1(b). A multiple regression linear model considering only the three factors mentioned is acceptable, as the residuals show no bias and a close to normal distribution with an average close to zero.

These results show that the dosage of fining agent required for wine protein removal based on the ethanol test would be done in excess, because the quantification considers also the influence of calcium-induced precipitation.

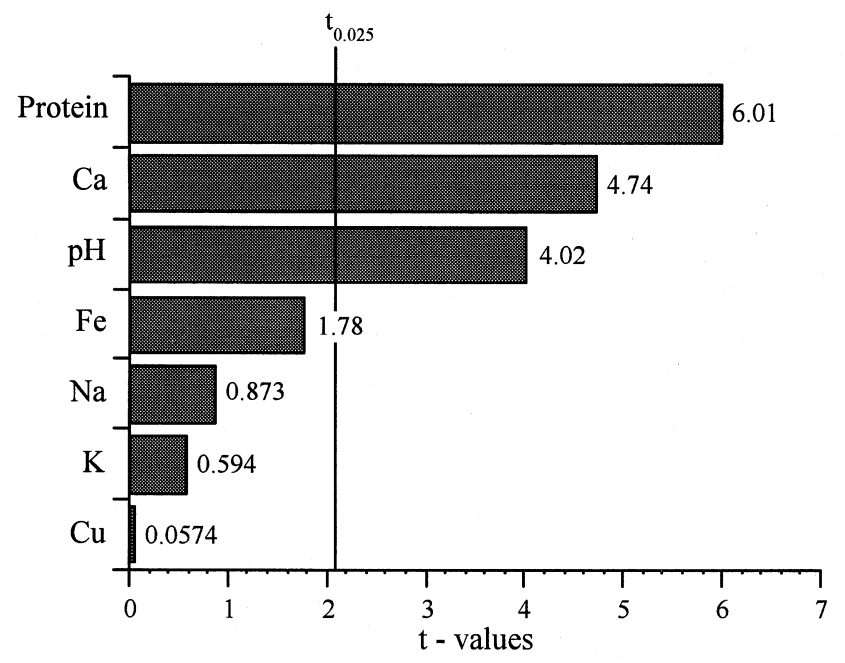

a)

\subsection{The heat test}

The results shown in Figs. 2 and 3 (for the fast and the mild versions, respectively) indicate that the developed haze depends only on the total protein content of the wines for both versions of the heat test. The diagnosis plots (Figs. 2(b) and 3(b)), indicate that a simple linear correlation between turbidity and total protein content is acceptable, with the residuals showing no bias and normal distributions with an average close to zero. The turbidity values obtained with the mild heat test were in general slightly higher than those of the fast heat test, although the differences were not statistically significant.

The heat test seems therefore to be an adequate indicator of total protein content for determining the amount of fining agent required to remove wine proteins.

\subsection{The tannin test}

The plot of induced haze vs. total protein, shown in Fig. 4, indicates that the degree of haze was limited by

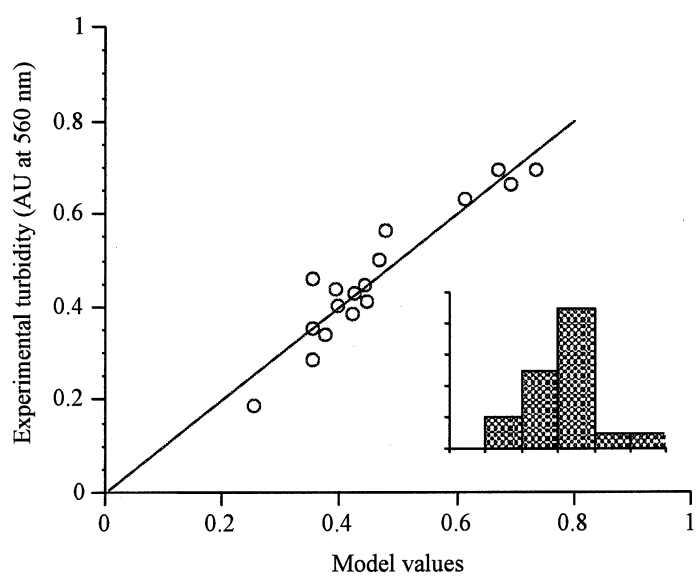

b)

Fig. 1. Stepwise multilinear regression for the ethanol test: (a) Pareto chart (the limit of significance for a $95 \%$ confidence level is indicated as a vertical line: effects of coefficients that do not reach this line are negligible); (b) Diagnosis plot of the multilinear model (the small graph indicates the distribution of the model residuals). 


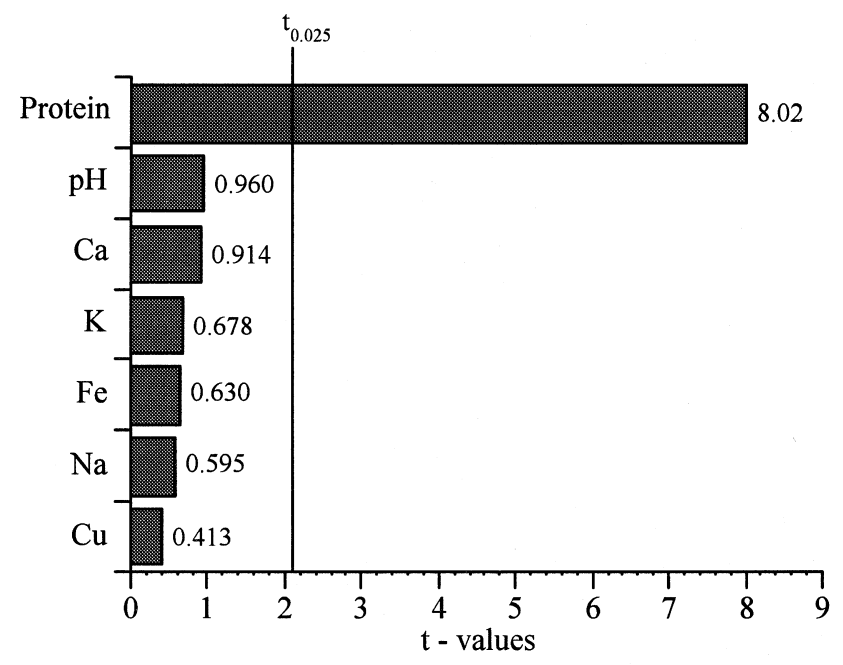

a)

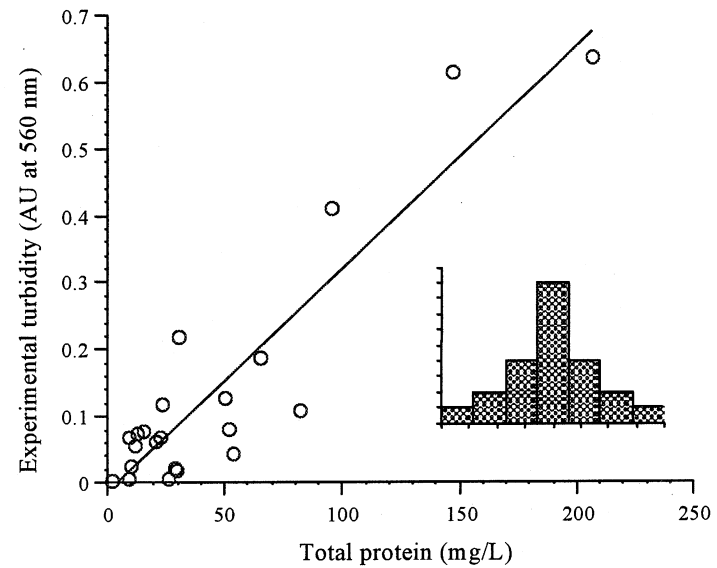

b)

Fig. 2. Stepwise multilinear regression for the "fast" heat test: (a) Pareto chart (the limit of significance for a 95\% confidence level is indicated as a vertical line: effects of coefficients that do not reach this line are negligible); (b) Diagnosis plot of the multilinear model (the small graph indicates the distribution of the model residuals).

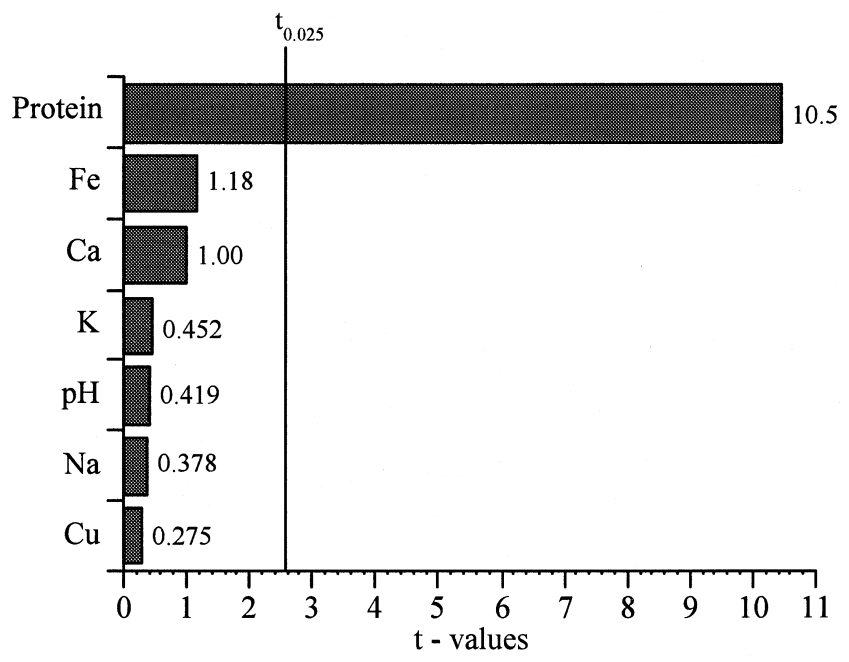

a)

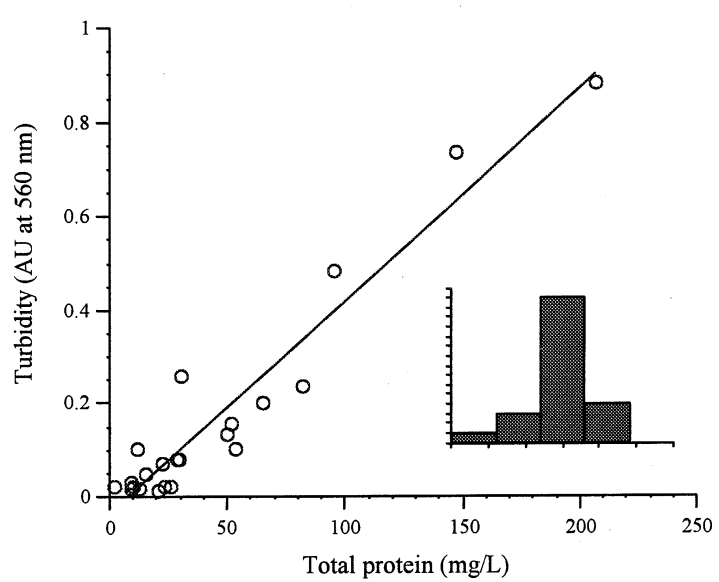

b)

Fig. 3. Stepwise multilinear regression for the "mild" heat test: (a) Pareto chart (the limit of significance for a $95 \%$ confidence level is indicated as a vertical line: effects of coefficients that do not reach this line are negligible); (b) Diagnosis plot of the multilinear model (the small graph indicates the distribution of the model residuals).

the amount of added tannin, which was due to a saturation effect. The samples above the saturation limit would require a higher amount of tannin than that recommended in the test procedure used. In one sample with high iron content, a visible black precipitate appeared, as a result of a tannin-iron instability (Ribéreau-Gayon, Paynaud, Ribéreau-Gayon \&
Sudraud, 1975), as indicated in Fig. 5 (wine sample with an iron content of $10.9 \mathrm{mg} / \mathrm{l})$.

A stepwise linear regression was performed using the data below saturation (total protein content below 70 $\mathrm{mg} / \mathrm{l})$ and the results obtained, shown in Fig. 5, indicate that this test is influenced by many factors: $\mathrm{pH}$, total protein content, iron content (as expected) and also 


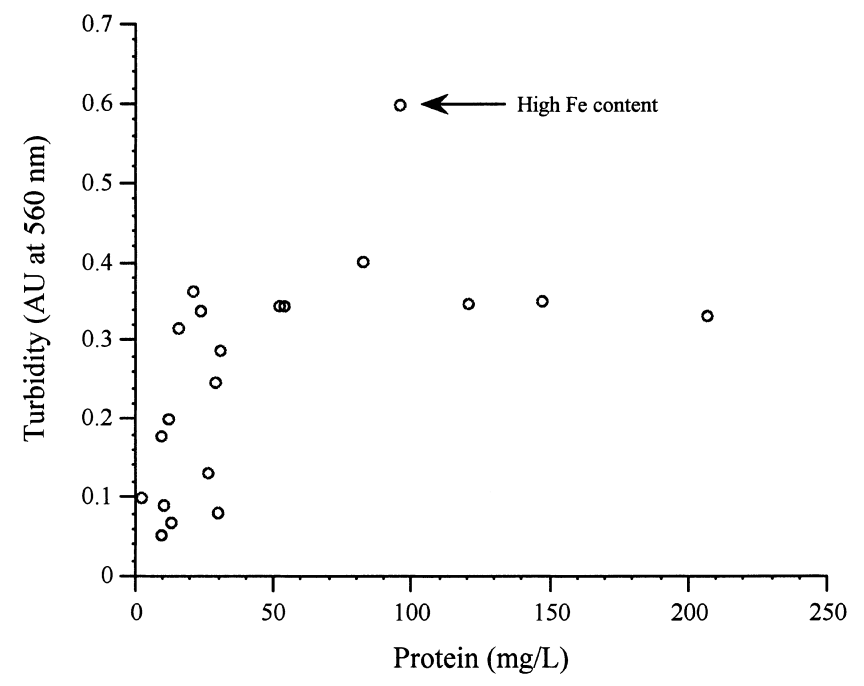

Fig. 4. Results of the tannin test for all samples.

potassium and copper concentrations. The two latter factors seem to have a stabilising effect, because the coefficients of the linear regression model are negative. Furthermore, the model shows some bias and the distribution of residuals is not close to normal. This may indicate a more complex interaction between factors and possible significant influence of other factors.

The tannin test is therefore affected by many intrinsic factors in the wine and is not recommended for determining the amount of fining agent required in stabilisation processes.

\subsection{Sensitivity of different protein fractions to natural precipitation}

After a one-year storage period at room temperature, a visible haze was found in four wines as a result of natural precipitation of the wine proteins. The extent of the precipitation is shown in Table 3, where the amount of protein that precipitated was obtained by difference of the total amount of protein of the wines after the oneyear storage (filtered through a $0.22 \mu \mathrm{m}$ membrane) compared to the original values.

A total of five wine samples were evaluated, four from the same region (Valpaços) and one from another (Algarve), namely AUMc, VUCd, VUFp, VUGv and VVGv (see Table 1 for reference legend). Typical protein profiles before and after the one-year storage are shown in Fig. 6. The differences were quite diverse from wine to wine, but in most cases, the protein profiles were very similar before and after the one-year natural precipitation. The extent of the precipitation was also diverse. However, some general features could be observed. New peaks that were not present in any of the original wine samples appeared after storage: new soluble protein fractions of lower molecular weight, with retention times around 6-11 min, that were due to physical or chemical modifications of the original fractions. It is interesting to note that, in general the fraction with the highest retention time (around $36 \mathrm{~min}$ ) showed a greater reduction than all others. The fraction with a retention time close to $17.5 \mathrm{~min}$ was also significantly affected: it was present in a small amount in only some wines (VUCd, VUFp

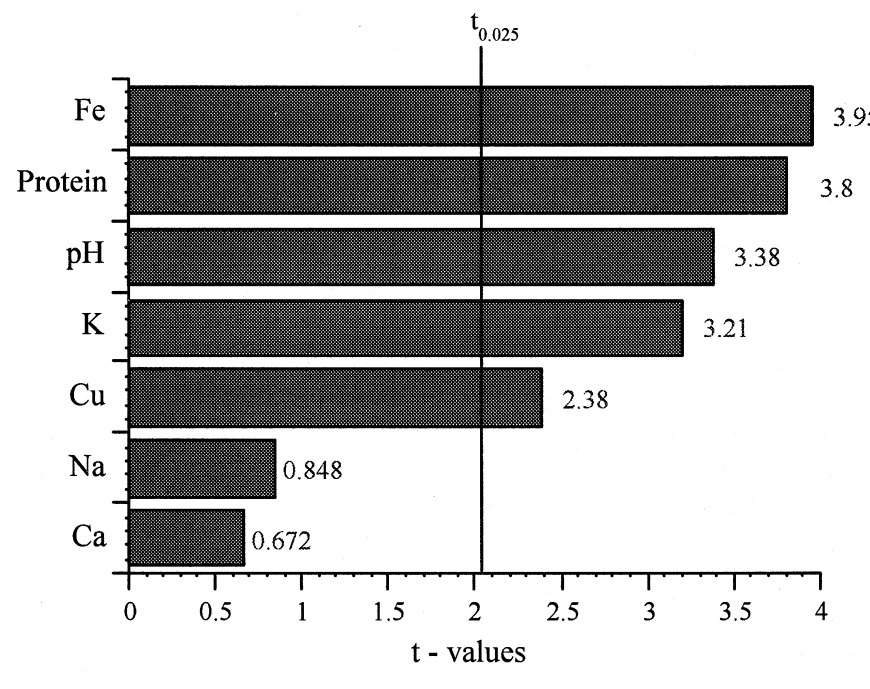

a)

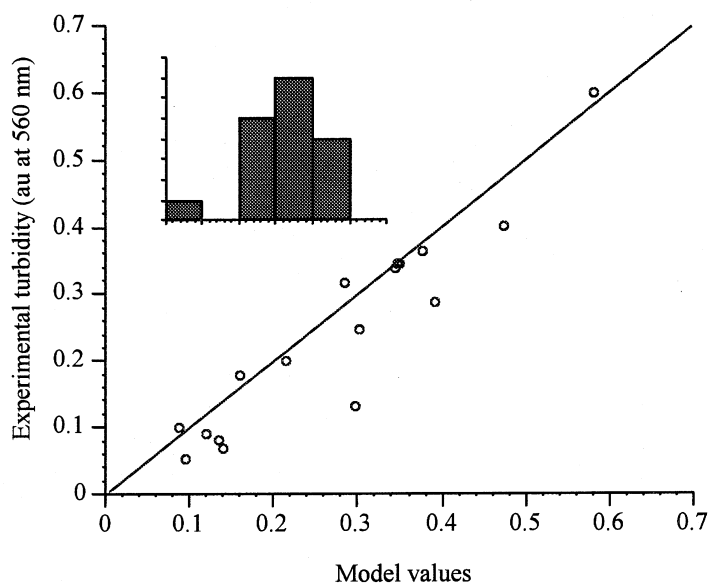

b)

Fig. 5. Stepwise multilinear regression for the tannin test, for samples with less than $70 \mathrm{mg} / \mathrm{l}$ initial protein content: (a) Pareto chart (the limit of significance for a $95 \%$ confidence level is indicated as a vertical line: effects of coefficients that do not reach this line are negligible); (b) Diagnosis plot of the multilinear model (the small graph indicates the distribution of the model residuals). 
Table 3

Turbidity developed in wine samples due to natural precipitation over a one year storage period (average of three replicates)

\begin{tabular}{|c|c|c|c|}
\hline Samples & Turbidity (AU at $560 \mathrm{~nm}$ ) & Initial protein content $(\mathrm{mg} / \mathrm{l})$ & $\begin{array}{l}\text { Amount of protein that } \\
\text { precipitated ( } \% \text { of the initial) }\end{array}$ \\
\hline VUCd & 0.125 & 53.7 & 71.5 \\
\hline AtUPr & 0.158 & 30.6 & 100.0 \\
\hline VUFp & 0.268 & 82.2 & 57.7 \\
\hline VVGv & 0.681 & 206.8 & 90.4 \\
\hline
\end{tabular}

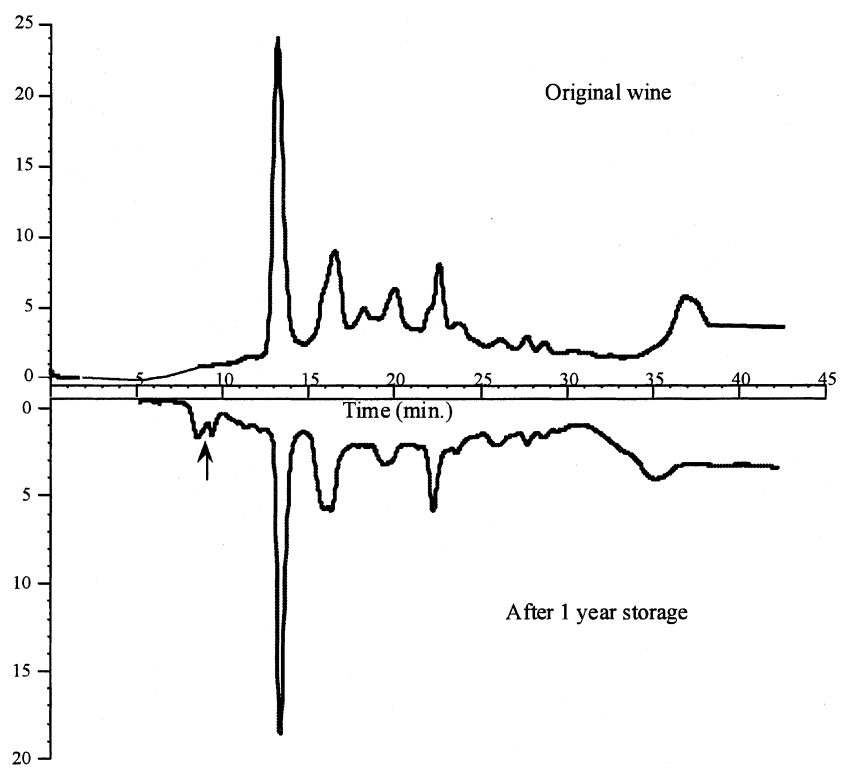

a)

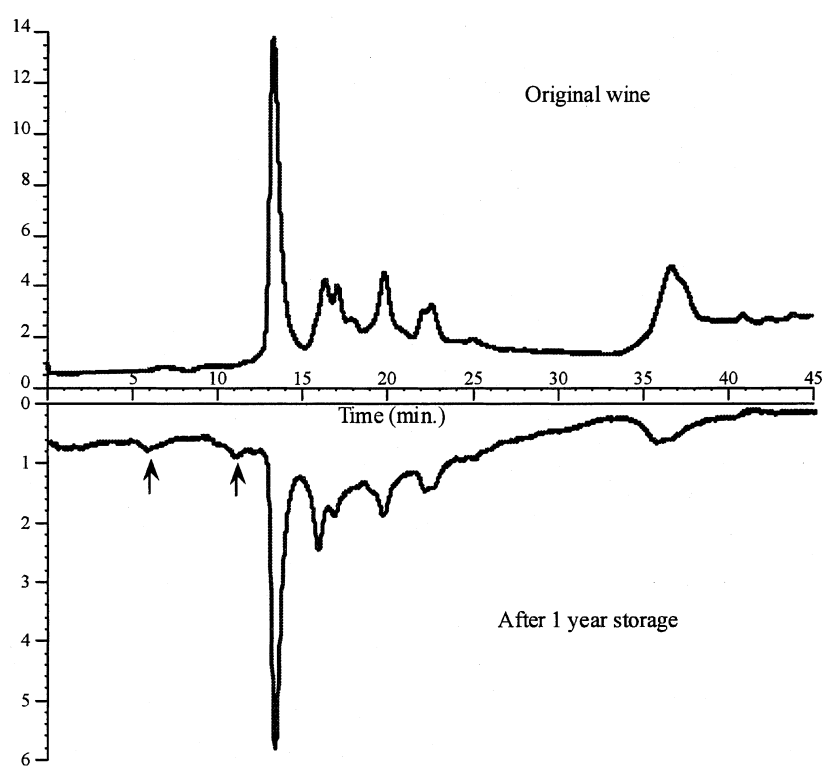

b)

Fig. 6. Typical chromatograms of: (a) AUMc; (b) VUCd wine samples. A chromatogram of an original sample is shown on top and one of a sample after the storage period is shown below in an inverse scale. New peaks showing after the storage period are indicated with arrows. and VVGv), and disappeared after storage. Among these five wines, one showed a difference in the protein profiles before and after the natural precipitation much greater than the others: VUFp had significant fractions with around 17, 20 and 23 min retention times that were more significantly reduced by the natural precipitation.

These observations are sufficient to conclude that natural precipitation does not change the protein profile of wines greatly, although a different tendency of the different fractions to precipitate is visible. It does seem that the best way to ensure protein stability is to remove all fractions - none of the fractions detected was stable.

\subsection{Influence of tannin, ethanol, $p H$ and temperature on wine protein stability}

The wines that originally had a significant amount of total protein but did not develop a visible haze after oneyear storage were selected for this study (AUMc, VUGv and VUMv).

The normal plots of the effects estimated are shown in Fig. 7. Points falling outside the line suggested by the majority correspond to effects that are relevant. It can be seen that the results for the three wine samples are relatively similar: in general the most important factor is the change in concentration of tannins, that has a interactive effect with $\mathrm{pH}$ and with temperature, and temperature and $\mathrm{pH}$ also show relevant individual effects. Only the variation in ethanol content (up to 15\%) does not affect the turbidity.

The interactive effects tannin - temperature and tannin $\cdot \mathrm{pH}$ were similar for the three wines. A detailed analysis showed that in fact the only relevant factor was the addition of tannins, because the other factors only affect the protein haze when tannin was added: in the samples without added tannin, $\mathrm{pH}$ and storage temperature did not affect the results.

It can therefore be concluded that, for determining the amount of fining agent required to remove wine proteins in stabilisation processes, neither blending nor the time between production and testing affect protein haze significantly, except if a variation in the tannin content has occurred. This factor, which is particularly relevant in rosé wines, should therefore be adequately monitored. 


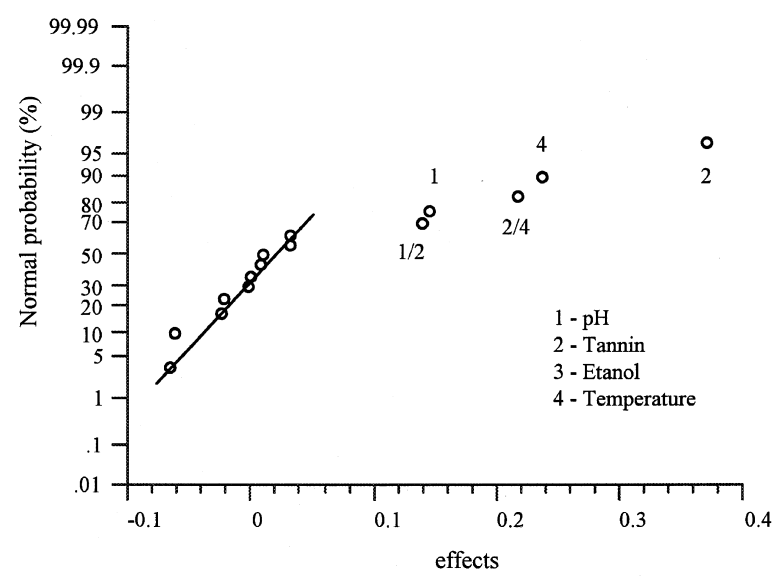

a)

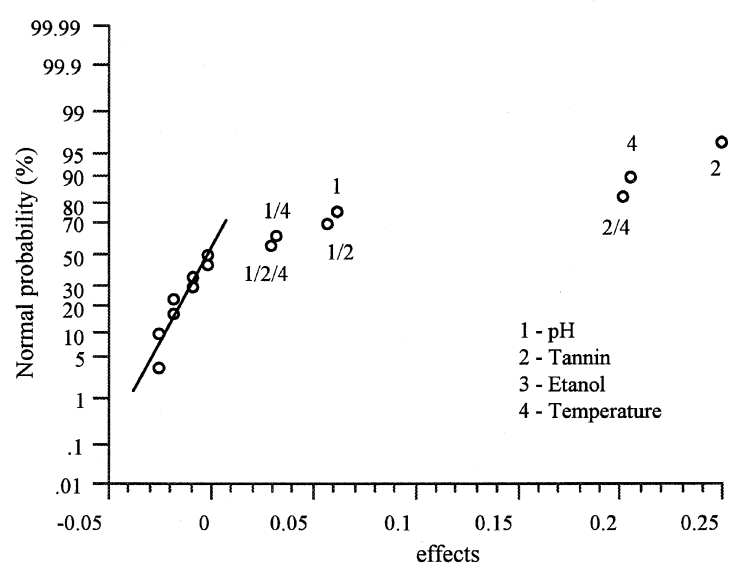

b)

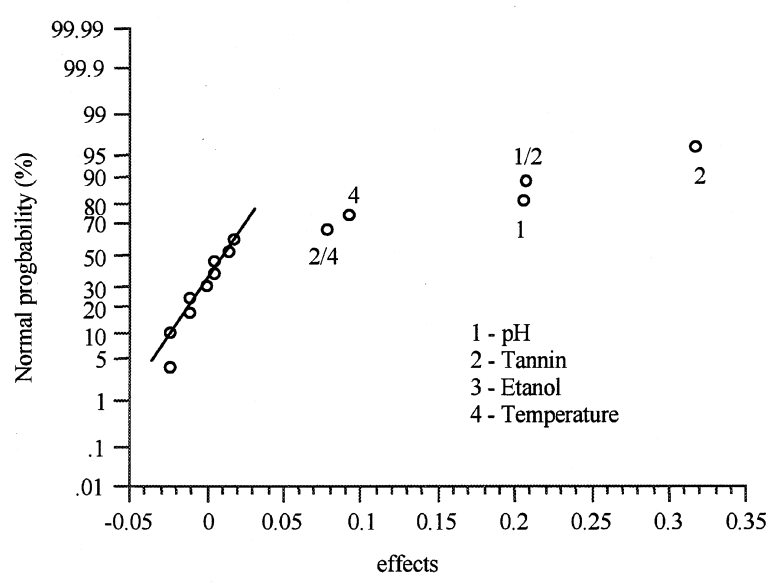

c)

Fig. 7. Normal plots of the effects of the factorial design: (a) AUMc samples; (b) VUGv samples; (c) VUMv samples. Points falling outside the straight line are statistically significant. Interactive effects between factors $i$ and $j$ are indicated as $i / j$.

\section{Conclusions}

Heat tests appear to be an adequate method to quantify the total amount of protein susceptible to precipitation and that must be removed in the production of most white and rosé wines, the results being relatively unaffected by intrinsic factors in the wine, such as $\mathrm{pH}$ and metal cations. Ethanol tests are sensitive to interference caused by calcium content and $\mathrm{pH}$ and tannin tests to $\mathrm{pH}$, iron, potassium and copper contents.

New protein fractions appeared after a one-year storage, indicating possible conversions of one protein fraction to another. All proteins showed a similar tendency to precipitate, as the wine protein profiles before and after one-year storage were generally similar. Therefore, it seems reasonable to establish that wine stability is better defined in terms of total protein content to ensure adequate storage stability.

The protein haze caused by protein precipitation is relatively unaffected by ethanol content and if significant variations in tannin content occur due to modifications during storage or arising from blending, then $\mathrm{pH}$ and temperature changes may then also affect the results.

\section{References}

Bayly, F. C., \& Berg, H. W. (1967). Grape and wine proteins of white wine varietals. American Journal of Enology and Viticulture, 17, 18 32.

Boulton, R. (1980). The nature of wine proteins. In Proceedings of the sixth annual wine industry technology seminar of the wine institute (pp. 46-58). San Francisco, CA, USA.

Dawes, H., Boyes, S., Keene, J., \& Heatherbell, D. (1994). Protein instability of wines: influence of protein isoelectric point. American Journal of Enology and Viticulture, 45(3), 319-326.

Haggerman, A. E., \& Buttler, L. G. (1981). The specificity of proanthocyanidin-protein interactions. Journal of Biological Chemistry, 256(9), 4494- 4497.

Hair, Jr., J. F., Anderson, R. E., Tatham, R. L., \& Black, W. C. (1995). Multivariate data analysis. Englewood Cliffs, NJ: Prentice-Hall.

Hsu, J. C., Heatherbell, D. A., Flores, J., \& Watson, B. (1987). Heatunstable proteins in grape juice and wine. I - characterisation and removal by bentonite finning and heat treatment. American Journal of Enology and Viticulture, 38(1), 11-16.

Lamikanra, O., \& Inyang, I. D. (1988). Temperature influence on muscadine wine protein characteristics. American Journal of Enology and Viticulture, 39(2), 113.

Lehninger, A. L. (1981). Biochemistry. New York: Worth.

Mesrob, B., Gorinova, N., \& Tsakov, D. (1983). Characterisation of the electrical properties and molecular weights of the proteins in white wines. Nahrung, 27(8), 727.

Ribéreau-Gayon, J., Peynaud, E., Ribéreau-Gayon, P. \& Sudraud, P. (1975). Traité d'oenologie sciences et techniques du vin (p. 3), Paris, France: Dunod.

Troost, G. (1988). Technologie des weines. Germany: Eugen Ulmer Verlage.

Trousdale, E., \& Boulton, R. (1987). The fractionation and quantification of wine proteins by three HPLC methods. In Presented at 
the 38th annual meeting of the American society for enology and viticulture.

Waters, E. J., Wallace, W., \& Williams, P. J. (1991). Heat haze characteristics of fractionated wine proteins. American Journal of Enology and Viticulture, 42(2), 123.

Waters, E. J., Wallace, W., \& Williams, P. J. (1992). Identification of heat-unstable wine proteins and their resistance to peptidases. Journal of Agriculture and Food Chemistry, 40, 1514-1519.
Waters, E. J., Shirley, N. J., \& Williams, P. J. (1996). Nuisance proteins of wines are grape pathogenesis-related proteins. Journal of Agriculture and Food Chemistry, 44, 3-5.

Yokotsuka, K., Yoshii, M., Aihara, T., \& Kushida, T. (1983). Turbidity formation caused by the interaction of must proteins with wine tannins. Journal of Fermentation Technology, 61, 413. 